\title{
Comparing thin- and thick-skinned thrust tectonic models of the Central Apennines, Italy
}

\author{
R. S. J. Tozer ${ }^{1}$, R. W. H. Butler ${ }^{1}$, and S. Corrado ${ }^{2}$ \\ ${ }^{1}$ School of Earth Sciences, University of Leeds, Leeds, LS2 9JT, U.K. \\ ${ }^{2}$ Dipartimento di Scienze Geologiche, Università degli Studi di Roma Tre, Largo San Leonardo Murialdo 1, 00146 Roma, \\ Italy
}

Received: 21 January 2001 - Accepted: 15 March 2001

\begin{abstract}
The geological structure of the Central Apennines along a section line across the Lazio-Abruzzi carbonate platform has traditionally been interpreted using a thin-skinned thrust tectonic model, in which the sedimentary cover has been detached from an undeformed basement below. Such models have been used to predict that very large amounts of crustal shortening (e.g. $172 \mathrm{~km}$ over a section $173 \mathrm{~km}$ long) have occurred. Alternatively, in this paper we reinterpret the surface geology and well data along the same section line using a thick-skinned thrust tectonic model. Restoration of this section shows that the amount of shortening ( $37 \mathrm{~km}$ over a section $158 \mathrm{~km}$ long) is considerably lower than previously predicted; this is accomplished by open buckling of the carbonate platform, tighter folding of the basin scarp stratigraphy, and reactivation of pre-existing extensional faults. Age bracketing on thrust fault movement allows shortening rates for the two different models to be calculated; these are $<6 \mathrm{~mm} \mathrm{yr}^{-1}$ for the new interpretation, but over $24 \mathrm{~mm} \mathrm{yr}^{-1}$ for the equivalent thin-skinned model. This latter value is significantly greater than shortening rates reported for most other thrust belts, suggesting that thick-skinned tectonics is a more satisfactory explanation for the structure of this area. The two most important implications of this are that subthrust hydrocarbon plays are largely absent in the area, and Neogene contractional deformation in this part of the Apennines resulted in much less crustal shortening than previously predicted.
\end{abstract}

\section{Introduction}

The problem of the degree of detachment within the continental crust during shortening has been widely debated for many years (e.g. Coward, 1983). In any thrust belt there are two extreme models that can be applied to the surface geology; one is that the sedimentary cover is detached from the

Correspondence to: R. S. J. Tozer

(r.tozer@earth.leeds.ac.uk) underlying basement along fault planes with ramp-flat geometries (thin-skinned model). The alternative is that basement is also involved in the deformation along crustal-scale ramps (thick-skinned or inversion tectonic model).

These alternatives are illustrated in Fig. 1, a very simplified example modelled on any of the main carbonate ridges flanked by flysch in the Central Apennines of Italy (Fig. 2). The available data for this example comes from the surface geology and subsurface well data, yet two contrasting interpretations can be reached by examining this. In Fig. 1a uplift and folding of the Mesozoic strata (Cretaceous and Jurassic limestone, Triassic evaporites) to form the anticlinal ridge has resulted from thrusting of the hanging wall over a duplication of the stratigraphy in the footwall beneath. In contrast, uplift and folding in Fig. 1b is simply a consequence of reactivation (tectonic "inversion") of an earlier extensional fault in the basement. This fault originally hosted a greater thickness of Triassic evaporites than predicted in the thin-skinned model. Both interpretations are admissible (in the sense of Elliott, 1983) since they balance and conform to the data.

Choosing the correct interpretation may be of crucial importance for hydrocarbon exploration (Coward, 1996). In Fig. 1a the repeated Cretaceous and Jurassic limestone beneath the ridge are an ideal hydrocarbon reservoir since they are sealed by Triassic evaporites and tectonic burial may have driven hydrocarbon generation. However, this configuration is not present in Fig. 1b. In addition, the amounts of shortening are vastly different (Coward, 1996); $19 \mathrm{~km}$ for the thinskinned model but only $5 \mathrm{~km}$ for the thick-skinned model. This disparity offers an opportunity to test between the models. If the timing of deformation can be determined, the shortening rates for each interpretation can be calculated and compared with rates calculated in similar tectonic settings. It may also be possible to discriminate between the models by looking at facies and/or thickness changes in the exposed stratigraphy, but only if the early extensional fault also influenced deposition of these.

Our aim is to re-examine the central part of the Apennine thrust belt of Italy. The numerous structural studies of 


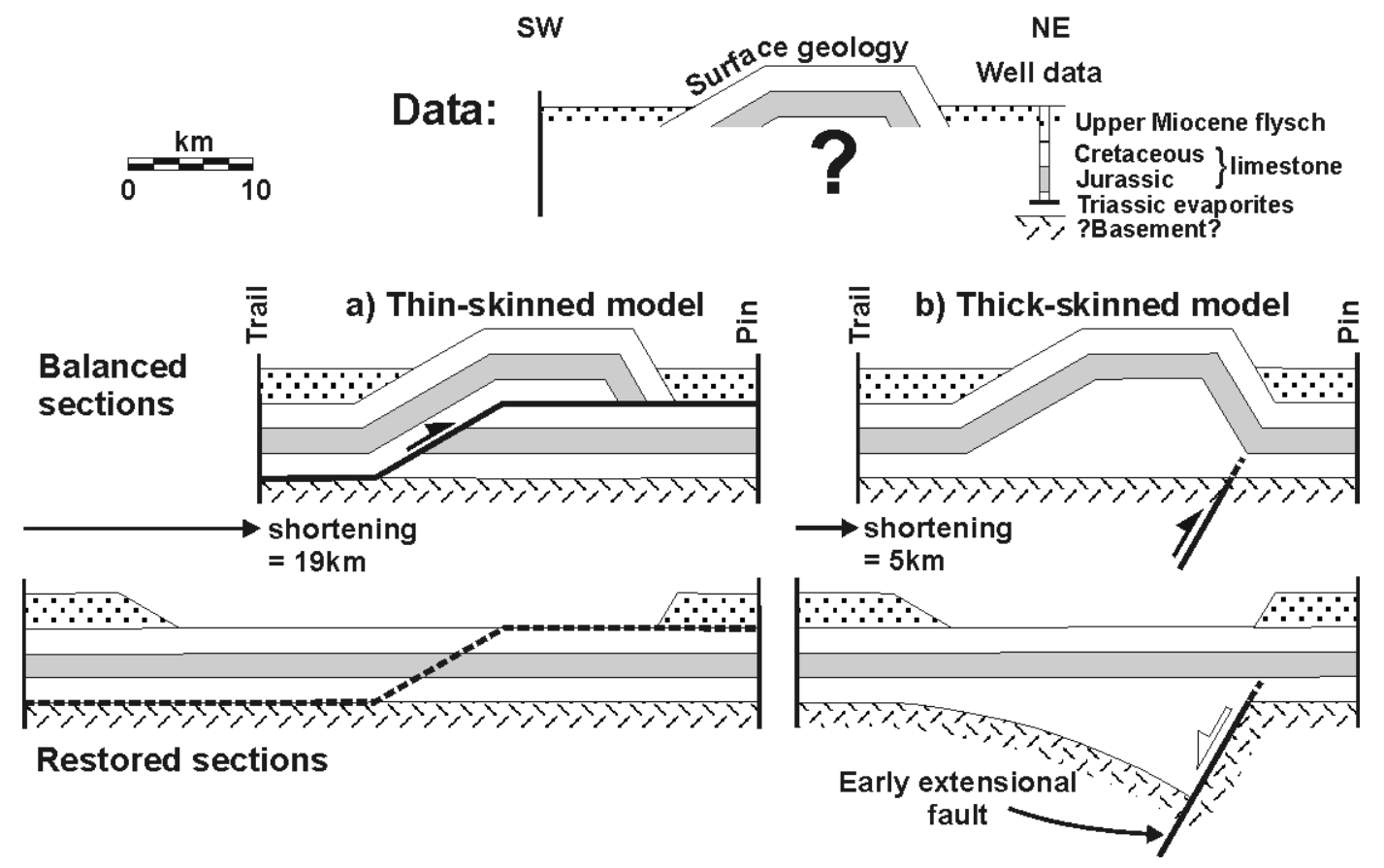

Fig. 1. Cross-sections illustrating two different interpretations of the same data from a hypothetical carbonate ridge flanked by flysch. In (a) uplift and folding have resulted from thin-skinned thrusting and duplication of the stratigraphy at depth. In contrast, uplift in interpretation in (b) is due to reactivation of a pre-existing extensional fault that originally hosted an increased thickness of sediment. Note that the shortening in (b) is almost four times less compared to (a).

this area are dominated by models in which the sedimentary cover is detached from an underlying hypothetical magnetic basement (Bally et al., 1986; Mostardini and Merlini, 1986; Hill and Hayward, 1988; Ghisetti et al., 1993; Cavinato et al., 1994). Such models have been used to support very large amounts of crustal shortening at rates $\left(\mathrm{c} .25 \mathrm{~mm} \mathrm{yr}^{-1}\right)$ significantly greater than those calculated for other thrust belts. However, in many other thrust belts, recent work has shown that thick-skinned basin inversion resulting from the reactivation of basement faults is an important deformation mechanism (Cooper and Williams, 1989; Buchanan and Buchanan, 1995).

In this paper we re-interpret the structure using a thickskinned tectonic model in which deformation of the basement and its overlying sedimentary cover is coupled. We explore the evidence in support of our interpretation together with some of its implications.

\section{Regional setting}

The Apennines include a Neogene thrust belt that forms the spine of the Italian peninsula with a vergence towards the Adriatic Sea (Fig. 2 inset). This, together with the onshore Gargano and Apulian promontories, constitutes the orogenic foreland. On a lithospheric scale, the thrust belt is dynamically linked to back-arc extension in the Tyrhennian Sea (Malinverno and Ryan, 1986; Faccenna et al., 1996 and references therein). Therefore the change in length due to hori- zontal extension in the Tyrrhenian Sea and the internal part of the chain is balanced by the change in length due to horizontal shortening within the thrust belt. This geodynamic process has operated since at least the late Miocene during which time the position of compression and then extension has migrated eastwards (Lavecchia, 1988; Lavecchia et al., 1994).

In the northern and central parts of the chain, thrusts are sealed by Pleistocene sediments or their corresponding subaerial surfaces, indicating that they were inactive by this time. In contrast, thrusting continues in the southern sector of the belt, with active subduction of Ionian oceanic lithosphere beneath the Calabrian Arc revealed by the distribution of intermediate and deep earthquakes (Giardini and Velonà, 1991) and tomographic imaging of the mantle (Lucente et al., 1999). This thrusting is balanced by the generation of new oceanic crust in the southern Tyrrhenian Sea (Faccenna et al., 1996, and references therein).

Our study is concerned with the Central Apennines (Fig. 2), an area in which the surface geology is well described and understood. In common with much of the Apennines, the area comprises southern Tethys passive margin sediments: basins, ramps and structural highs of Triassic to Miocene age (Parotto and Praturlon, 1975). These are dominated by various carbonate facies (platform, margin and basin) that are dissected by Cenozoic and Mesozoic faults. In our study area there are two distinct carbonate successions, both of Triassic to middle Miocene age: the LazioAbruzzi carbonate platform and the Gran Sasso platform 


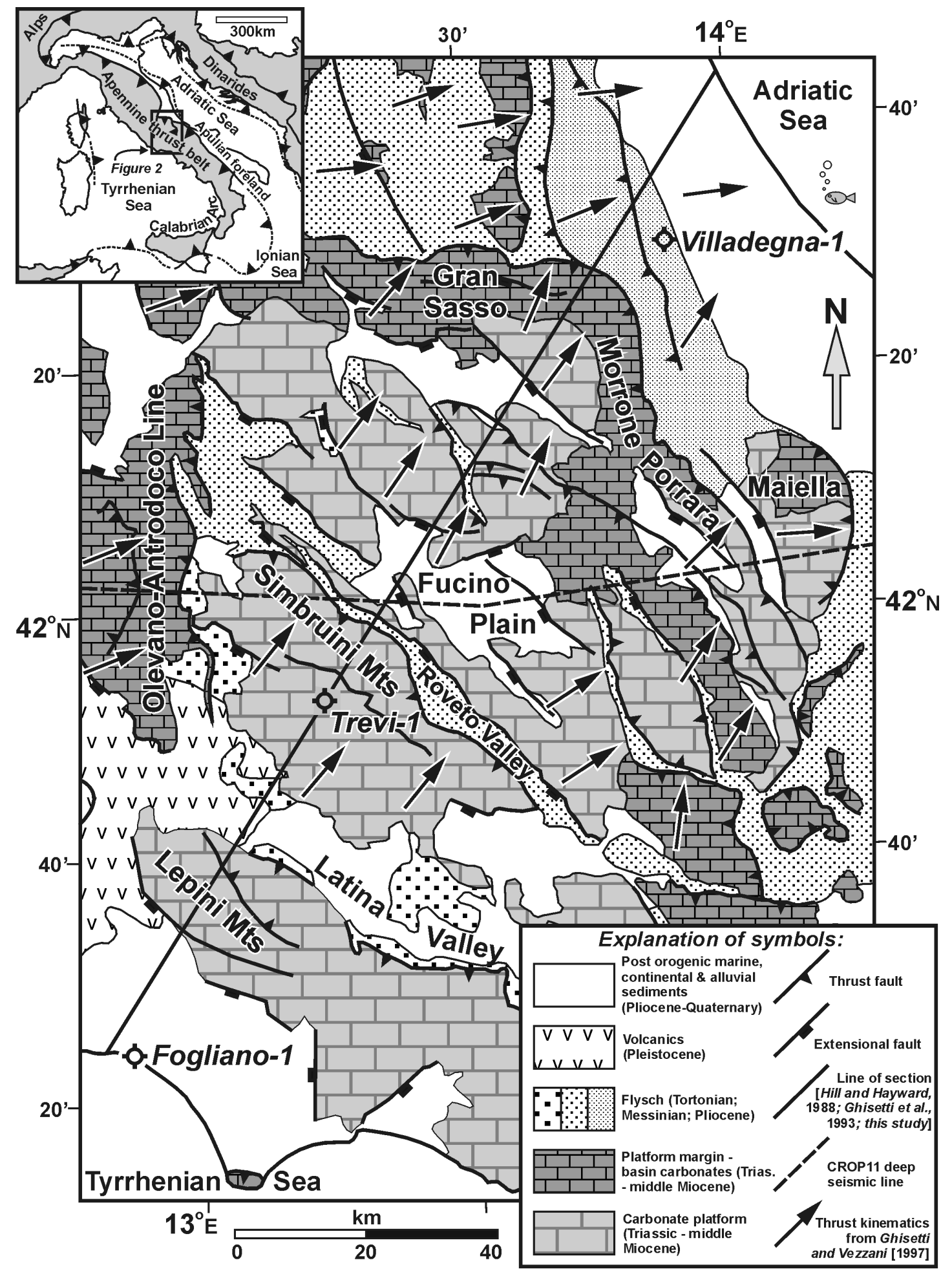

Fig. 2. Simplified geological map of the study area. The inset shows the location and regional setting. After Bigi et al. (1990).

margin/proximal basin scarp succession (Fig. 3). Between the major thrust-related culminations of these carbonates, late Miocene and Pliocene siliciclastics (flysch) overlie them. These are interpreted as the turbidite fill of foredeep basins that developed ahead of the active thrust front and were fed axially from the north. From south-west to north-east, the onlap of progressively younger flysch onto the pre-tectonic carbonates has been used to support a model of piggy-back thrusting that migrated towards the north-east (Cipollari and Cosentino, 1996). 


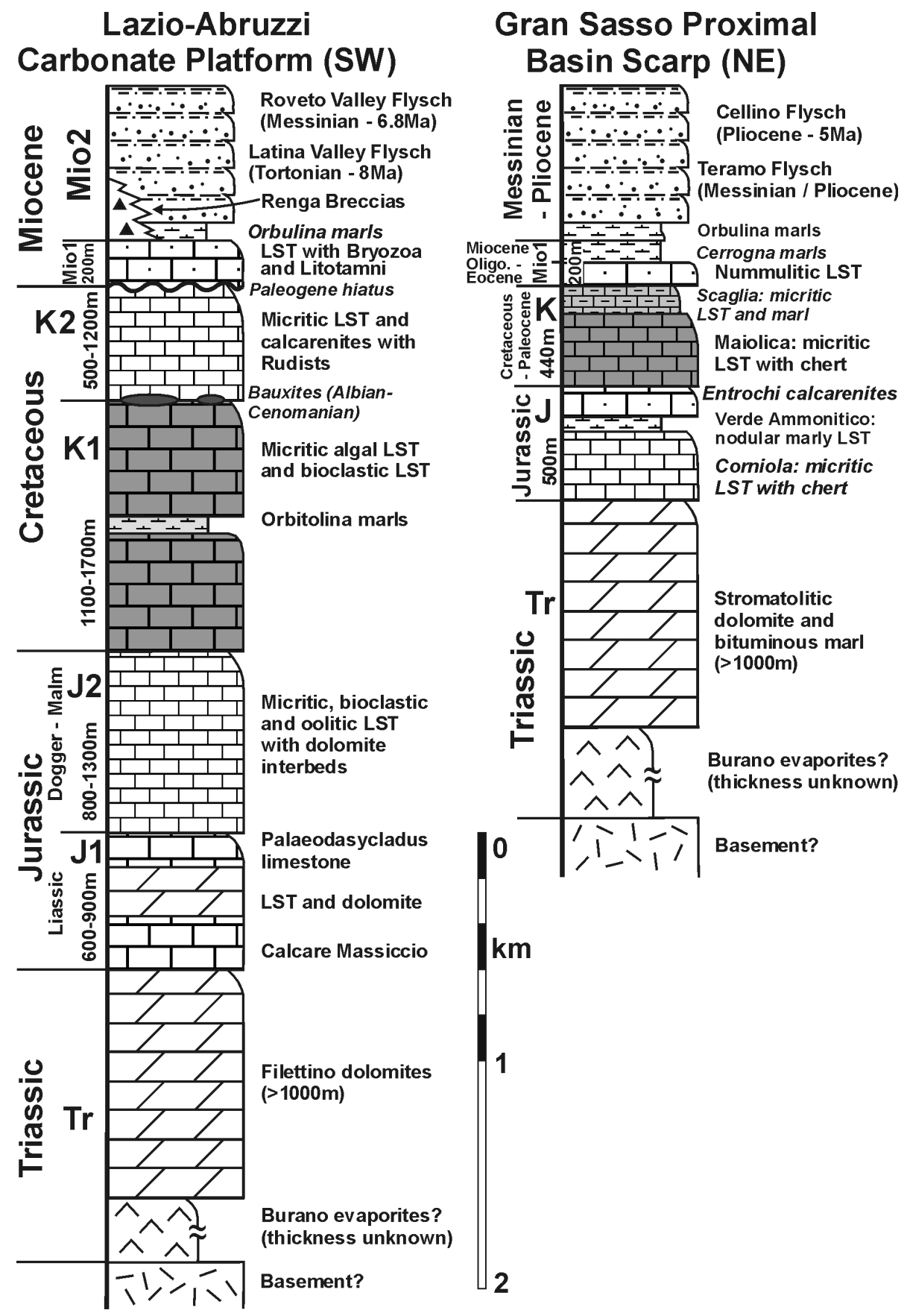

Fig. 3. Simplified stratigraphic columns of the two main carbonate successions along the line of section (Flysch not to scale). Although only the minimum cumulative thickness of the units comprising the Lazio Abruzzi carbonate platform is illustrated, this is still considerably thicker than the Gran Sasso succession. In part, this can be attributed to syn-sedimentary extensional faulting. Shaded units are also shaded in Fig. 6. The abbreviations Mio, K, J, and Tr refer to those used in Fig. 6; LST = limestone. Compiled from Parotto and Praturlon (1975); Alberti et al. (1975, 1997); Ghisetti and Vezzani (1986, 1997); Vezzani and Ghisetti (1998). Flysch ages from Cipollari and Cosentino (1996).

\section{Previous interpretations of Central Apennine struc- ture}

The section line across the Lazio-Abruzzi carbonate platform has been chosen since it allows a direct comparison with several previously published sections. Historically, many au- thors have used this section line since it crosses the centre of the Lazio-Abruzzi carbonate platform parallel to the direction of thrust transport and perpendicular to the major structures (Fig. 2). Thin-skinned models dominate the structural interpretations of this area; the evidence presented for these includes older-on-younger relationships in some wells, e.g. 
Trevi 1 (Dondi et al., 1966), the occurrence of evaporites of Triassic age at the base of the known stratigraphy, and absence of basement outcrop in the area. In addition, existing aeromagnetic data (Agip, 1981) show a planar, gently dipping magnetic basement at depths of c. $10 \mathrm{~km}$.

Within the published work several different methods of section construction have been used; here these are arranged by the levels of confidence proposed by Elliott (1983). Dimensionless shortening values (\% shortening or strain) are ambiguous in zones of heterogeneous strain where the line of section is not identical. Therefore we have standardised the reported values and presented them in terms of km shortening.

\subsection{Unbalanced sections - mathematical estimates}

Estimates of the amount of shortening based on a simple calculation of the total area above a planar magnetic basement, divided by an average thickness of the stratigraphy (Cavinato et al., 1994) have yielded high estimates of the minimum amount of shortening: $199 \mathrm{~km}$ over a section $151 \mathrm{~km}$ long. Alternatively, these authors suggested three explanations for this anomalously high shortening value. One is that the thrust belt may have evolved in two stages such that Neogene compression was superimposed on an earlier Alpine phase of deformation. The others are that significant volumes of foreland carbonates may have been incorporated within the thrust belt, or pre-Triassic basement may also have been involved in the deformation.

\subsection{Unrestored sections}

Mostardini and Merlini (1986) published a series of detailed sections across the Central and Southern Apennines based on 1:100000 geological maps and data from hydrocarbon wells. The SW half (Tyrrhenian coast to Val Roveto) of the most northerly of these sections (section 15) runs along the same section line as that used in this study. Whilst their sections are not restored, it is still possible roughly to quantify the shortening implied; the surface geology shows relatively limited shortening by nature of the "ramp on ramp" configuration of many of the thrusts. However, the gap between the surface stratigraphy (a layercake up to $5 \mathrm{~km}$ thick) and the magnetic basement (at depths of $10 \mathrm{~km}+$ ) is filled by duplication of the stratigraphy, resulting in an overall, large-scale, "flat on flat" geometry. This implies at least $140 \mathrm{~km}$ of shortening (total section length: $195 \mathrm{~km}$ ) even before the thrusts at the surface are considered.

\subsection{Restorable and admissible sections}

Hill and Hayward (1988) constructed 8 balanced sections across the Italian peninsula from the Po Valley to Sicily to constrain the Tertiary plate tectonic evolution of Italy. Section 3 of their study (based on geological maps and well data) is along the identical line to that used here, so direct comparison is possible. This section shows $157 \mathrm{~km}$ of shortening over a $226 \mathrm{~km}$ long section of the thrust belt; once again, this is mainly achieved by duplication of the entire stratigraphy at depth. However, the shortening value is misleading since Plio-Pleistocene extensional faults are interpreted as listric back-thrusts and therefore have not been removed before restoring earlier thrust faults. As a result, the actual post compressional length of the section ( $\mathrm{L}_{1}$ in this study) should be shorter and therefore the amount of shortening would be even higher.

Ghisetti et al. (1993) also used the same line of section, and produced both in- (Fig. 4) and out-of-sequence interpretations of the thrust belt. Recent work has thrown doubt on the interpretation of out-of-sequence thrusts. D' Agostino et al. (1998) found evidence that low angle "younger-on-older" tectonic contacts in the Gran Sasso thrust belt are actually extensional faults. Consequently, the amount of extension estimated by these authors in the Gran Sasso thrust belt is also very much greater; the reported value is between $25 \%$ and $75 \%$ along a present-day section $10 \mathrm{~km}$ long, so we infer between 2 and $4.5 \mathrm{~km}$ of extension over this. These values compare with only $7 \mathrm{~km}$ across the entire present-day chain $(178 \mathrm{~km})$ for the out-of-sequence interpretation of Ghisetti et al. (1993). A further problem with the out-of-sequence interpretation of Ghisetti et al. (1993) are the very high displacements on some of the out-of-sequence thrusts (these account for 81 of $116 \mathrm{~km}$ shortening along a section of $171 \mathrm{~km}$ ). If this were the correct interpretation then klippen should be found throughout the Central Apennines. However, they are very rare in this area and we consider that it is unlikely that they could have been removed entirely by erosion. In addition, the general in-sequence progression of deformation is demonstrated by foredeep sediments that become progressively younger towards the NE (Cipollari and Cosentino, 1996).

For these reasons we have chosen the section depicting in-sequence (piggy-back) thrusting (Fig. 4) for comparison with our work. The originally published version also extends offshore, but only the onshore portion is considered in this study. Total shortening in this interpretation is therefore $172 \mathrm{~km}$ (estimated measurement error $\pm 5 \mathrm{~km}$ ) over a section of $173 \mathrm{~km}$. As in the sections discussed previously, this is accomplished by replication of the entire stratigraphy at depth.

\subsection{Problems with thin-skinned models}

There are two particular problems with thin-skinned models. The first is that the length of the restored sedimentary cover in thin-skinned sections is greatly in excess of the length of the basement that is thought to underlie the thrust belt today. Similar problems in the Northern Apennines and other thrust belts can be explained by thrust shortening of the basement in the internal part of the orogen. However, this cannot be applied to the Central Apennines because basement rocks do not outcrop in this area. Therefore Ghisetti et al. (1993) suggested that large volumes of the continental lithosphere might have been subducted, although we are unaware of any evidence for this. 


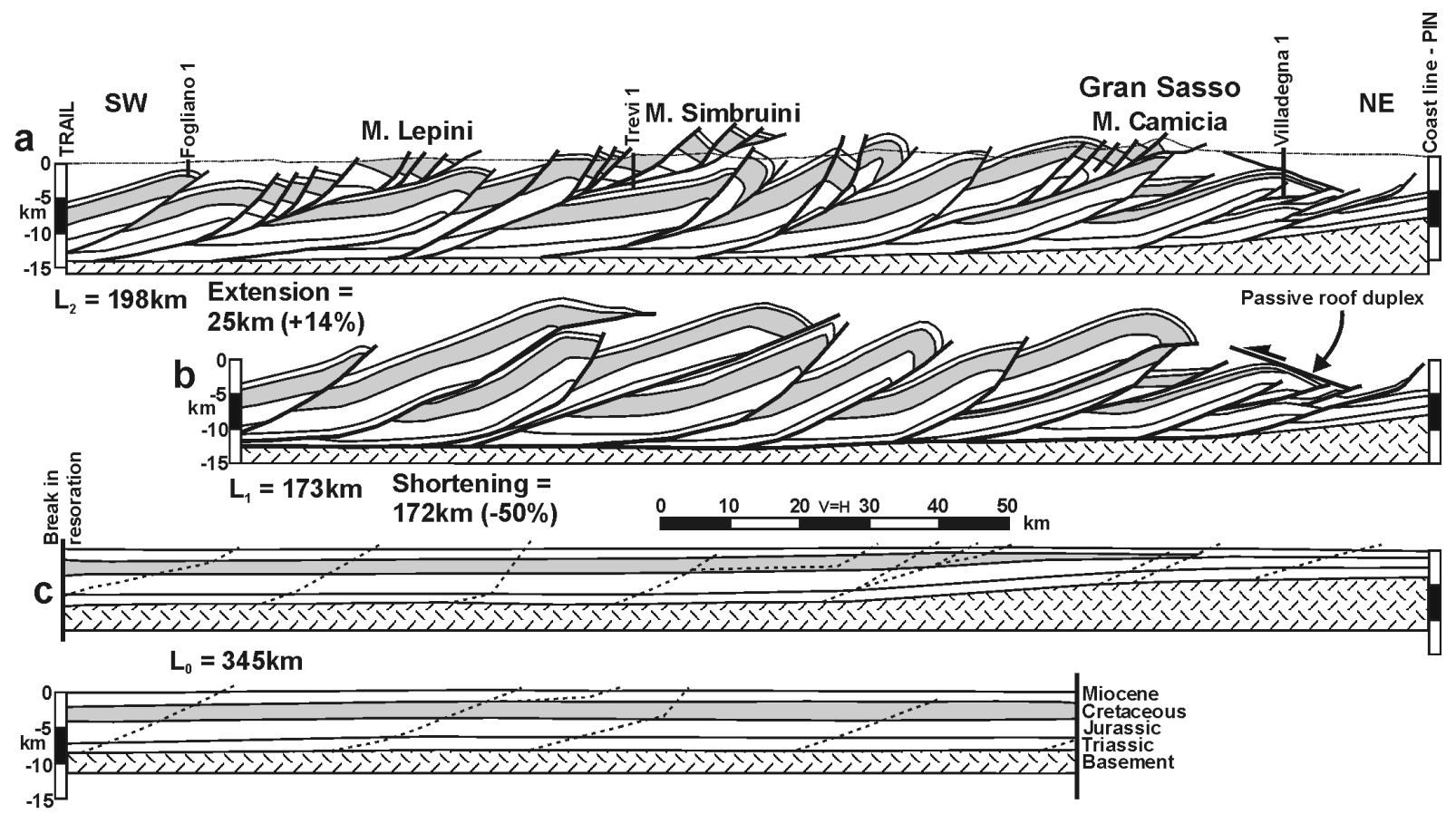

Fig. 4. Thin-skinned cross-section through the Central Apennines, modified after Ghisetti et al. (1993). (a) Present day section, PlioPleistocene normal faults in bold; (b) restoration after removal of Plio-Pleistocene normal faults, thrust faults in bold; (c) restored section after removal of thrust faults (dashed).

The second problem is that at the mountain front on the eastern side of the Gran Sasso thrust belt the Mesozoic stratigraphy has been greatly uplifted relative to its elevation beneath the Adriatic Sea. In thin-skinned models this is accomplished by three-fold repetition of the stratigraphy at depth, resulting in a high concentration of displacement in this area. Despite these large displacements, flysch in the foreland is relatively undeformed. This paradox can be explained by a hypothetical passive-roof duplex at the mountain front, as illustrated by Bally et al. (1986) and Ghisetti et al. (1993) (Fig. 4b). These structures are thought to accommodate deformation beneath a relatively stationary layer of foreland strata, in this case flysch (Banks and Warburton, 1986). However, such structures present mechanical difficulties; Vann et al. (1986) reason that backthrusting of the overlying foreland must occur above a roof thrust that is being folded by duplexing beneath.

\section{Different interpretations of Apennine structure}

New research from the Northern Apennines (Coward et al., 1999; Mazzoli et al., 2000; Butler et al., in press) has shown that thick-skinned (inversion) tectonic interpretations can readily be applied to the external part of the thrust belt. In particular, Butler et al. (in press) show that inversion reinterpretation of the Marche area requires five times less shortening than the alternative thin-skinned model of Bally et al. (1986). However, inversion interpretations cannot universally be applied to the Apennines. Well data in the South- ern Apennines (Lucania and Molise regions) clearly demonstrates the presence of allochthonous thrust sheets that have been transported $>45 \mathrm{~km}$ over autochthonous Apulian platform carbonates (Mazzoli et al., 2000; Butler et al., in press). This configuration forms an important hydrocarbon play in this region (Pieri and Mattavelli, 1986; Casero et al., 1991).

The Central Apennine sector considered in this study lies between the Marche and Molise areas analysed by Butler et al. (in press). Therefore, it might be expected that the structural style would contain elements of both thin-skinned thrusting and thick-skinned inversion. The former is well documented in our study area since the Trevi 1 well encountered older-on-younger relationships (Triassic on Cretaceous on Miocene, Fig. 5) $14 \mathrm{~km}$ behind the frontal thrust of the Simbruini Mountains. In spite of this, thick-skinned tectonic ideas can still be applied to produce an interpretation radically different to previous work in the area.

4.1 Evidence for thick-skinned tectonics in the Central Apennines

New aeromagnetic data (Chiappini et al., 2001) suggests that magnetic basement rocks may have been involved in the compressional deformation. This is in contrast to the existing data (Agip, 1981), in which the pattern of anomalies indicates a planar basement. In any case, magnetic integrity cannot be used as an indication of structural integrity. In Fig. 1, for example, the top of the basement in both balanced sections (a) and (b) is in an identical position despite their very different deformation histories. 

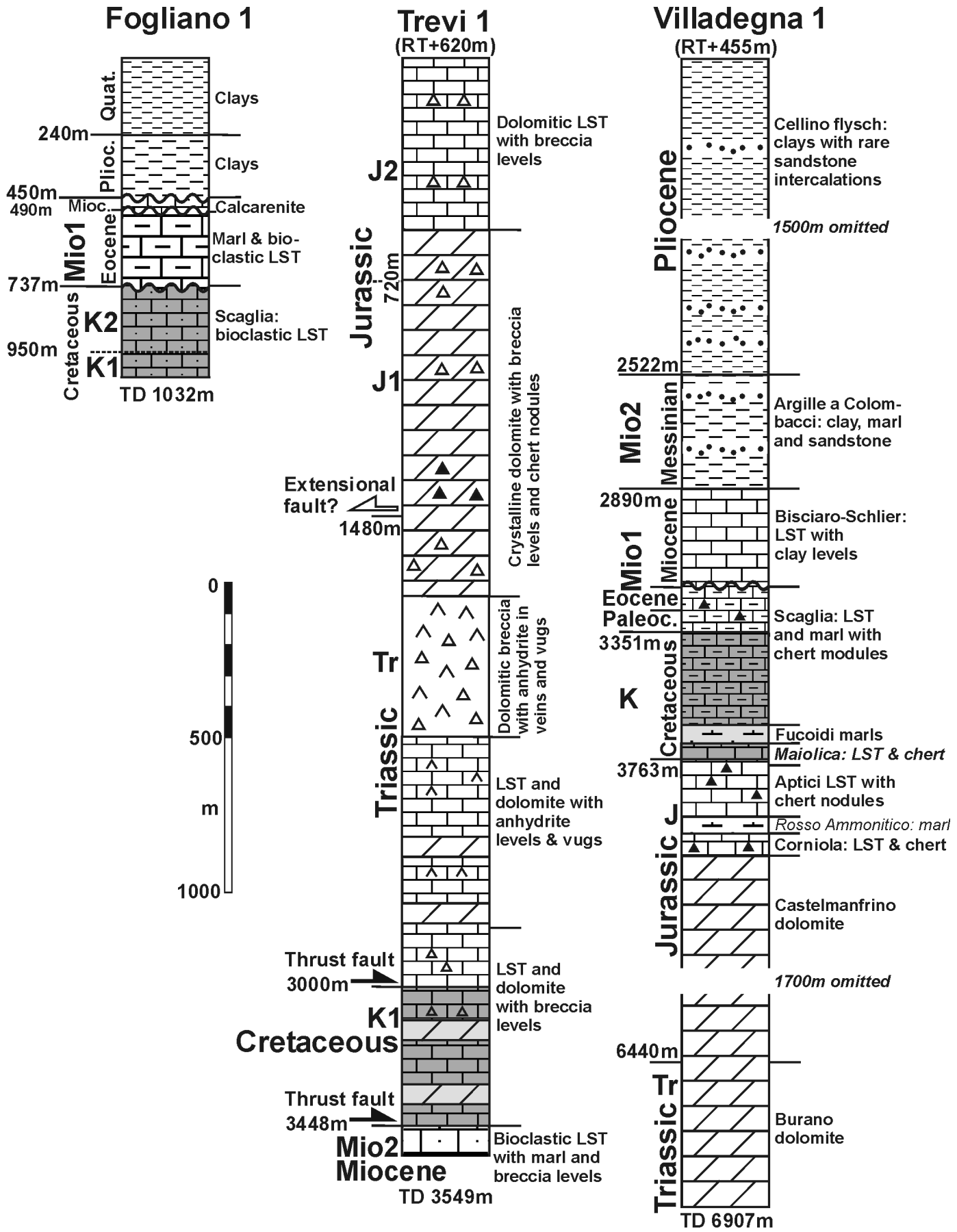

Fig. 5. Simplified well logs from the Fogliano 1 (Segre et al., 1963; Parotto and Praturlon, 1975), Trevi 1 (Dondi et al., 1966) and Villadegna 1 wells. Depths in metres below rotary table (RT). Shaded units are also shaded in Fig. 6. The abbreviations Mio, K, J, and Tr refer to those used in Fig. 6; LST = limestone.

The CROP03 deep seismic profile in the Northern Apennines reveals that the basement was involved in thrusting even in the external part of the thrust belt (Barchi et al., 1998a). The geological interpretation of the profile (Barchi et al., 1998b) also shows that the Moho is stepped as a consequence of thrusting, and at least one similar step is thought to be present in the Central Apennines beneath the Roveto Valley (Cavinato et al., 1994). In addition, reactivated ex- tensional faults are evident in seismic reflection data from the Adriatic Sea (Fig. 7 of Argnani and Gamberi, 1995), and onshore seismic reflection profiles from the Southern Apennines indicate that the buried Apulian autochthon has a characteristic thick-skinned structural style (Mazzoli et al., 2000).

The presence of early extensional faults is well known and is demonstrated by abrupt lateral variations in facies 

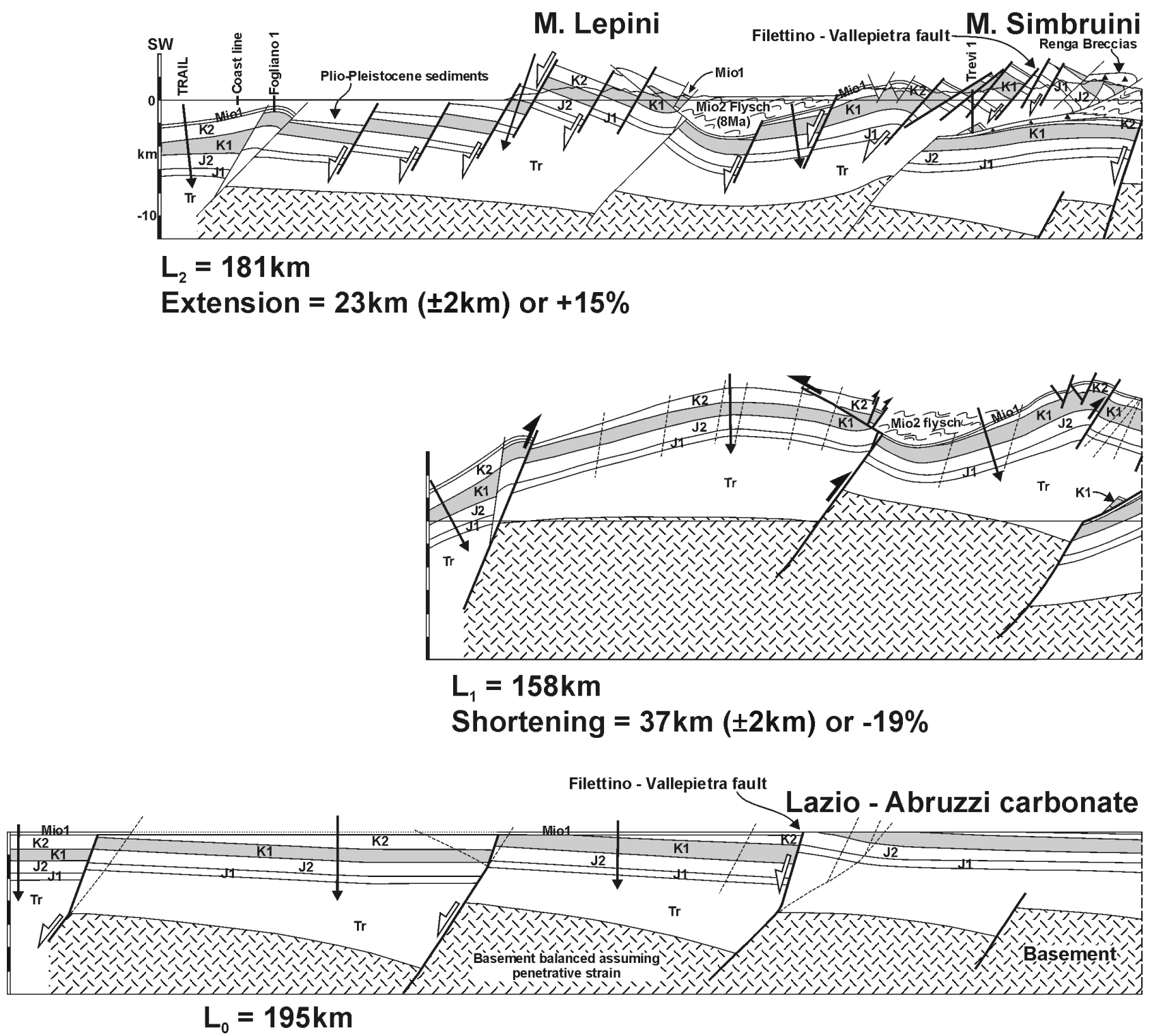

Fig. 6. Cross-section through the Central Apennines constructed using a thick-skinned thrust tectonic hypothesis; refer to Figs. 3 and 5 for details of the stratigraphy and unconformities. Flysch ornament is schematic. Arrows through the stratigraphy are pin lines. ( $\left.\mathrm{L}_{2}\right)$ Present day cross-section, Plio-Pleistocene extensional faults in bold. $\left(\mathrm{L}_{1}\right)$ Idealized restoration after removal of Plio-Pleistocene extensional faults (dashed). Bold lines indicate thrusts and reactivated faults. $\left(\mathrm{L}_{0}\right)$ Restored section after removal of thrust and reverse faults (dashed). Early/syn-sedimentary extensional faults in bold (Fig. 6 continues next page).

and thickness of the Mesozoic stratigraphy (e.g. Parotto and Praturlon, 1975; Barchi and Bigozzi, 1995). In particular, the transition from the Lazio-Abruzzi carbonate platform to the Gran Sasso proximal basin scarp succession is accompanied by a dramatic thinning of the Jurassic to middle Miocene stratigraphy (from over $3000 \mathrm{~m}$ to only $1000 \mathrm{~m}-$ Fig. 3); in part this can be attributed to syn-sedimentary faults.

Some thrusts have small-scale structures indicating northeast vergence yet have finite extensional throws of the Mesozoic stratigraphy. For example, the Filettino-Vallepietra fault in the Simbruini Mountains has been documented as a thrust that has placed Cretaceous limestone in the hangingwall over Liassic and Triassic dolomites (Devoto, 1970). This con- figuration is consistent with contractional reactivation of a pre-existing normal fault where the extensional displacement was greater that the thrust displacement. The kinematics within the fault zone indicate strike-slip where fault planes have steep dips, and oblique, normal or reverse slip where planes dip more gently (Cavinato et al., 1994). Reverse and strike-slip kinematics can be interpreted as the consequence of strain accommodation within the fault zone during transpressive reactivation, a common feature of reactivated extensional faults (Coward, 1996). We interpret the exposure of unusually old Liassic and Triassic dolomites on the northeast side of this fault to be the result of paleo-erosion of the early extensional fault footwall. Subsequent shortcut thrust- 

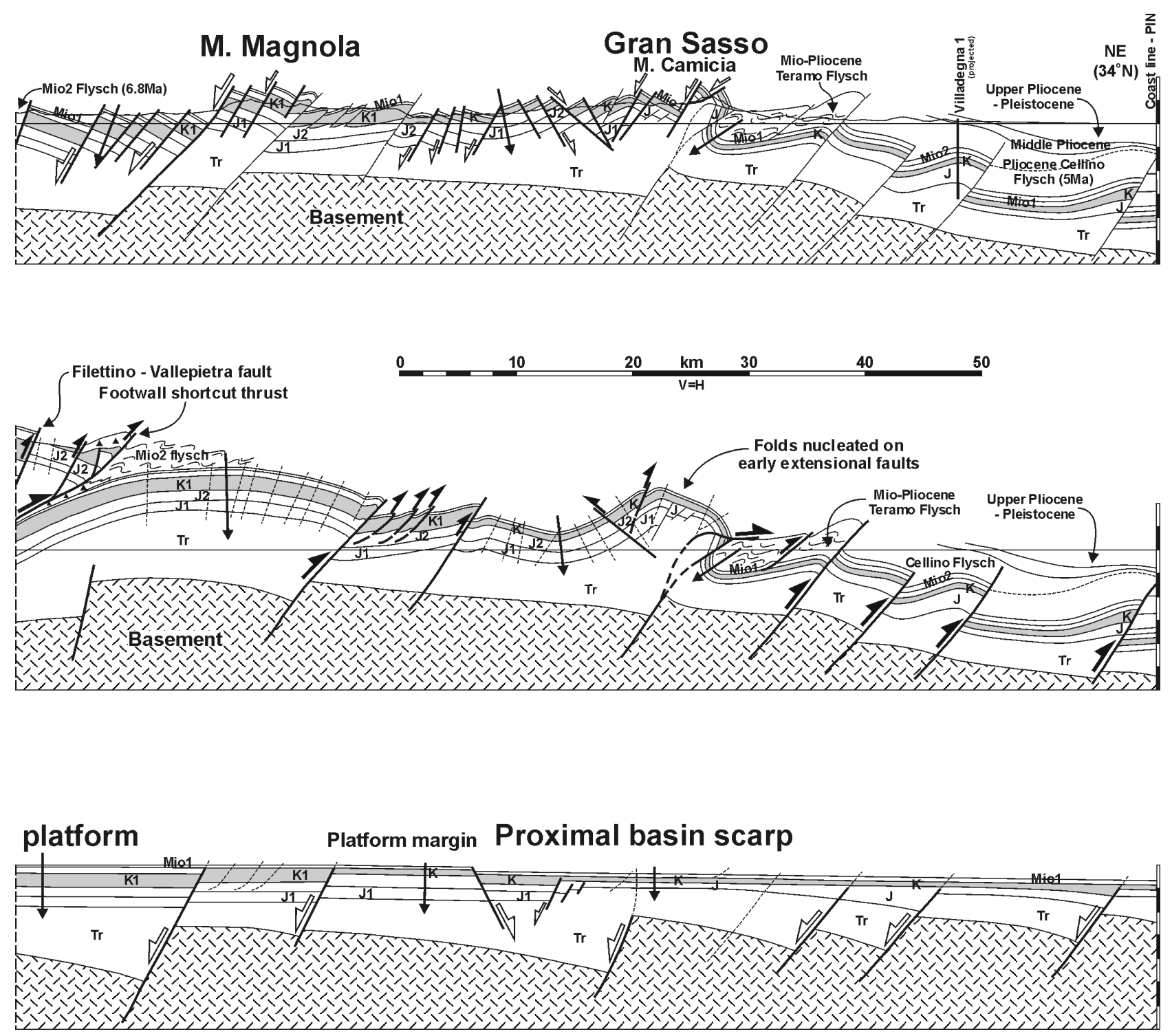

Fig. 6. ... continued.

ing across the footwall, a typical feature of inversion tectonics (Coward, 1996), has resulted in the preservation of this structure in the centre of the Simbruini Mountains.

\section{Method of construction and restoration of a thick- skinned tectonic section}

\subsection{Data}

The new section (Fig. 6) was originally constructed and restored at 1:100000, using 1:100000 (Segre et al., 1963, 1966; Vezzani and Ghisetti, 1998) and more detailed geological maps of the area (Alberti et al., 1975, 1997; Ghisetti and Vezzani, 1986) supplemented by additional field data from key areas. Data from the Fogliano 1, Trevi 1 and Villadegna 1 wells (Fig. 5) has also been included to provide control on deeper structure. Unfortunately, few seismic reflection profiles and well data are available within the Mountain chain for logistical reasons; this area contains the greatest elevations in the Apennines (Corno Grande - $2912 \mathrm{~m}$ ). At the mountain front next to the Adriatic Sea, the sub-surface structure has been constrained from base Pliocence isobaths and subsurface thrust data of Bigi et al. (1990).

Thicknesses of the Jurassic and younger stratigraphy were taken from the wells, deduced from the maps, and taken from associated cross-sections and measured-sections. The deep structure and stratigraphy are entirely hypothetical and this is one of the major problems for all sections across this area. In particular, basement steps are shown in the new section at as little as $4 \mathrm{~km}$ depth and it would be expected that magnetic anomalies would show these. However, the presence of a magnetic basement is also hypothetical, and Paleozoic sediments and low-grade metasediments (i.e. non-magnetic) are well known from the internal zones of the Northern Apennines (e.g. Bortolotti et al., 1970). 


\subsection{Assumptions}

The stratigraphy of the cross-section is dominated by the Lazio-Abruzzi carbonate platform units. Where thrust sheets of these strata are exposed they show very little internal strain and therefore simple line-length restorations may be applied to the surface geology with confidence.

A complication arises due to possible out-of-plane displacements since conventional section balancing requires plane strain. However, thrust transport directions along the line of section are variable and range from $35^{\circ} \mathrm{N}$ across the carbonate platform to $20^{\circ} \mathrm{N}$ in the Gran Sasso thrust belt and $80^{\circ} \mathrm{N}$ the Laga Mountains (Fig. 2) (Ghisetti and Vezzani, 1991; Cavinato et al., 1994; Ghisetti and Vezzani, 1997). In addition, rotations about vertical axes are all recorded for parts of the central Apennines; these have been detected by palaeomagnetic work, e.g. Mattei et al. (1995). In common with many other thrust belts these complexities are concentrated in areas of important oblique ramps, for example the northern flank of the Abruzzi region in the Gran Sasso thrust belt. In our analysis we have chosen a section line that avoids the oblique ramp zones as much as possible.

Strike-slip faulting is commonly observed in the Apennines, and this complicates simple two dimensional restorations. However, strike-slip faulting in the Lazio-Abruzzi region is of relatively limited significance in comparison with more southern areas of the Apennines (e.g. Mattei and Miccadei, 1991; Corrado et al., 1997), and so two dimensional restoration can still be applied.

\subsection{Restoration}

Structural reconstructions of the thrust belt are complicated by Plio-Pleistocene extensional faults related to the migrating zone of crustal stretching in the orogenic interior. Therefore a two step restoration was applied, the first step of which $\left(\mathrm{L}_{2}\right.$ to $\left.\mathrm{L}_{1}\right)$ is the removal of these; this was done by back rotation of fault blocks according to domino-faulting theory. We have made a simplistic assumption that beneath the faulted Jurassic and younger stratigraphy the Triassic sediments have deformed in a ductile manner without a change in volume (i.e. cross-sectional area). The resulting section $\left(\mathrm{L}_{1}\right)$ shows a post-compressional configuration that is idealised, since compression in the most external part of the section was coeval with extension in the internal part, i.e. the relief on the reconstruction is not realistic.

The second step of the restoration is the removal of thrust faults in order to return the section to a pre-deformational (middle Miocene) state, $\mathrm{L}_{0}$. This was done using line length on the base of the lower Miocene and then using a combination of line-length and area balancing above and below this to achieve compatible shortening between all the layers. In this way we have accommodated both pure and simple shear deformation; for example the minor thrusts to the NE of Monte Magnola are shown to die out into a zone of pure shear at depth. Area balancing is also suited to the restoration of non-layercake areas such as the Triassic of our section. How- ever, line lengths of the top basement are not identical in all the stages, and we suggest that the minor line-length/volume changes can be explained by penetrative deformation of these rocks, i.e. cleavage formation. Another assumption of this stage of the restoration was that regional interbed slip during compression was not significant; therefore loose lines drawn perpendicular to bedding in sections $\mathrm{L}_{2}$ and $\mathrm{L}_{1}$ were assumed to have been perpendicular also in section $\mathrm{L}_{0}$.

These simplifications and the assumptions mean that all sections drawn along this line are only crude approximations, as already noted by Ghisetti et al. (1993).

\section{Results of thick-skinned tectonic interpretation}

Plio-Pleistocene extension of $23 \mathrm{~km}$ (estimated drafting error $\pm 2 \mathrm{~km}$ ) is calculated from comparison of sections $\mathrm{L}_{1}$ and $L_{2}$ (Fig. 6). This is likely to represent only a minimum value of the extension since more detailed work in the Gran Sasso area (D'Agostino et al., 1998) identifies local extension of between 2 and $4.5 \mathrm{~km}$ over c. $10 \mathrm{~km}$. This is accommodated by two generations of extensional fault, so a single step restoration is simplistic.

The consequence of adopting a thick-skinned tectonic hypothesis is that the original length $\left(\mathrm{L}_{0}, 195 \mathrm{~km}-\right.$ Fig. 6) is considerably shorter than previous estimates (commonly c. $350 \mathrm{~km})$. From this and the post compressional length $\left(\mathrm{L}_{1}\right.$, $158 \mathrm{~km}$ ), the amount of shortening is calculated as just $37 \mathrm{~km}$ (estimated drafting error $\pm 2 \mathrm{~km}$ ). This is accomplished entirely by reactivation of early extensional faults, open buckling of the carbonate platform with a wavelength of $10 \mathrm{~s} \mathrm{~km}$, and tighter folding of the of the thinner and more incompetent basin-scarp stratigraphy. This tighter folding can be seen in the part of the section $\mathrm{L}_{1}$, around what is now the Gran Sasso thrust belt. The anticline - syncline pair (with minor forelimb thrusts) has nucleated in an area where Jurassic syn-sedimentary extensional faults are present, an association also identified in the Northern Apennines by Tavarnelli (1996).

\section{Discussion: thin-skinned vs. thick-skinned tectonics}

Both the thin-skinned section of Ghisetti et al. (1993) (Fig. 4) and the new interpretation presented here (Fig. 6) are equally admissible since they both honour the outcrop and well data, and can be restored. Simply comparing the different interpretations is insufficient to discriminate between them since evidence for both exists; this is a good illustration of the assertion that "a balanced section is not a unique solution" (Elliott, 1983). Therefore an additional test is required, and calculation of the shorting rates for both interpretations can provide this. In this way it is possible to test the sections to a level beyond section restoration alone.

The timing of thrusting in the Central Apennines can be constrained by simple age bracketing on the thrust faults, i.e. thrusts are younger than the rocks they cut, but older than rocks that overlie them. At each of the major thrusts, the last 
Table 1. Comparison of thrust belt shortening rates

\begin{tabular}{|c|c|c|c|c|c|}
\hline Thrust belt & $\begin{array}{c}\text { Shortening } \\
/ \mathbf{k m}\end{array}$ & $\begin{array}{c}\text { Time for } \\
\text { shortening / Myr }\end{array}$ & $\begin{array}{c}\text { Rate / mm } \\
\mathbf{y r}^{-1}\end{array}$ & Method & Author \\
\hline Coastal Range, Taiwan & - & (5 years) & $11-82$ & GPS & Yu et al. (1997) \\
\hline Southern Apennines & c. 400 & 8 & 50 & $\begin{array}{l}\text { Foredeep/thrust } \\
\text { front migration }\end{array}$ & Patacca et al. (1990) \\
\hline Central Apennines & 172 & 7 & $24.6( \pm 5)$ & Section balancing & Ghisetti et al. (1993) \\
\hline Central Andes & - & (5 years) & $19-24$ & GPS & Kendrick et al. (1999) \\
\hline Himalayas & - & (6 years) & $18( \pm 2)$ & GPS & $\begin{array}{l}\text { Bilham et al. (1997) } \\
\text { Larson et al. (1999) }\end{array}$ \\
\hline Himalayas & - & - & $14( \pm 4)$ & $\begin{array}{l}\text { Average rate of } \\
\text { all methods }\end{array}$ & $\begin{array}{l}\text { Powers et al. (1998) } \\
\text { and references therein }\end{array}$ \\
\hline $\begin{array}{l}\text { Himalayan front, } \\
\text { NW India }\end{array}$ & $\begin{array}{c}23 \\
5-10.6 \\
\end{array}$ & $\begin{array}{l}1.5-1.9 \\
0.7-0.8 \\
\end{array}$ & $\begin{array}{c}14( \pm 2) \\
6-16 \\
\end{array}$ & Section balancing & Powers et al. (1998) \\
\hline Northern Alps & $46-53$ & $4.1-5.4$ & $8.5-12.9$ & Onlap migration & Sinclair (1997) \\
\hline Western Alps & $29-33$ & $4.1-5.4$ & $4.9-8.0$ & Onlap migration & Sinclair (1997) \\
\hline Central Apennines & 37 & 7 & $5.3( \pm 1)$ & Section balancing & This study \\
\hline Sicily & c. 25 & c. 5 & c.5 & $\begin{array}{l}\text { Allochthon time } \\
\text { bracketing }\end{array}$ & Butler et al. (1992) \\
\hline Pyrenees & 147 & 62 & 2.4 & Section balancing & Muñoz (1991) \\
\hline
\end{tabular}

deposits that were cut by thrusting are flysch sediments on the external side of the main thrust fault in the area (Fig. 2). The oldest flysch is found along the Latina Valley, the oldest and most internal paleo foredeep. Dating by Cipollari and Cosentino $(1995,1996)$ shows that this flysch was deposited entirely during the $\mathrm{CN} 9 \mathrm{a}$ subzone (late Tortonian: $8-7.2 \mathrm{Ma})$. Therefore we have used $8 \mathrm{Ma}( \pm 0.5 \mathrm{Myr})$ as the earliest age of thrusting along the sections.

Subsequently, the depocentres of younger flysch migrated to the north-east (Fig. 2); this is demonstrated by sediments of early Messinian age $(6.8 \mathrm{Ma})$ along the Val Roveto and late Messinian - early Pliocene (c.5 Ma) sediments east of the Morrone-Porrara thrust (Teramo flysch and Cellino Formation of Vezzani and Ghisetti, 1998). This arrangement has been used to support a model of piggy-back thrusting across the area, in which the active thrusts moved progressively towards the north-east. Since the most north-eastern surface thrust along our section line is sealed by late Pliocene sediments (Castilenti Formation of Vezzani and Ghisetti, 1998), this could be used to date the end of thrusting. Indeed, previous work (Cipollari and Cosentino, 1996) estimated that thrusting had finished by the Middle Pliocene. However, we have used a more conservative Pleistocene age (1 Ma $\pm 0.5 \mathrm{Ma}$ ) for the end of thrusting, to account for the possibility that movement continued on more internal thrusts. This age is well constrained as Pleistocene sediments overlie all the thrusts.

Therefore all the onshore shortening occurred between 8 and $1 \mathrm{Ma}$ (both are $\pm 0.5 \mathrm{Myr}$ ), i.e. in a period of $7 \mathrm{Myr}$ $( \pm 1 \mathrm{Myr})$. Average shortening rates for the two different in- terpretations can therefore be calculated:

Thin-skinned interpretation (Fig. 4):

$172( \pm 5) \mathrm{km}$ in $7( \pm 1) \mathrm{Myr}$

$=24.6 \mathrm{~km}$ in $1 \mathrm{Myr}$

$=24.6( \pm 5) \mathrm{mm} \mathrm{yr}^{-1}$

Thick-skinned interpretation (Fig. 6):

$37( \pm 2) \mathrm{km}$ in $7( \pm 1) \mathrm{Myr}$

$=5.3 \mathrm{~km}$ in $1 \mathrm{Myr}$

$=5.3( \pm 1) \mathrm{mm} \mathrm{yr}^{-1}$

There is a varied picture of shortening rates in other thrust belts (Table 1), and rates for the previous models of Central Apennine structure are comparable with present-day GPSdetermined rates in other thrust belts. However, in general they are much higher than those reported in the Mediterranean area. An interesting comparison is with the Pyrenees where similar amounts of shortening to those suggested by Ghisetti et al. (1993) and Hill and Hayward (1988) are reported (147 km: Muñoz, 1991). In contrast to the Apennines, the shortening took place over $62 \mathrm{Myr}$ (cf. $7 \mathrm{Myr}$ ) during the Cretaceous and Paleogene. Detailed studies (Meigs et al., 1996) have shown that this did include short periods $(<1 \mathrm{Myr})$ during which the shortening rate reached almost $30 \mathrm{~mm} \mathrm{yr}^{-1}$. However, the average rate for the $62 \mathrm{Myr}$ period was only $2.4 \mathrm{~mm} \mathrm{yr}^{-1}$.

Cipollari and Cosentino (1996) calculated even higher rates of $40 \mathrm{~mm} \mathrm{yr}^{-1}$ for the Central Apennines since they ascribed all thrusting to the Tortonian - Early Pliocene, a 
shorter interval than we have used in this study. These authors suggested that the very high shortening rates in the Central and Southern Apennines compared to other thrust belts may be explained by the hypothesis of eastward mantle flow (Doglioni, 1993a, 1993b). Alternatively, anomalous shortening rates in the Central Apennines may simply be a consequence of applying the wrong structural model to the area (Coward, 1996). The new thick-skinned interpretation provides a much more reasonable shortening rate whilst still honouring the outcrop and well data.

\section{Wider implications}

If, as the shortening rates suggest, thick-skinned tectonics was the dominant deformation style in the Central Apennines there are several important implications.

Miocene and Pliocene crustal shortening in the Central Apennines is much less than previously estimated. This shortening was mainly accommodated by reactivation of preexisting extensional faults and folding of the carbonate platform and basin scarp sediments, as opposed to shortening dominated by thrust faulting in previous studies. Future paleogeographic reconstructions and geodynamic models should take this into account. In addition, whilst thin-skinned rates in the Central Apennines are comparable with some of the fastest rates reported for present-day thrust belts, along-strike changes in the Apennine thrust belt indicate a southerly increase in the amount and rate of shortening (Patacca et al., 1990; Mazzoli et al., 2000; Butler et al., in press). Therefore shortening rates of c. $50 \mathrm{~mm} \mathrm{yr}^{-1}$ calculated for the Southern Apennines (Patacca et al., 1990 - Table 1) are significantly higher than rates reported for other thrust belts. This study has established that the amount and rate of shortening in the Central Apennines may be much less than previously estimated, so a more conservative reappraisal of the Southern Apennines may therefore be appropriate.

Since major thrust sheets are not developed in the thickskinned model, the initial accommodation space in foreland basins that was subsequently filled by flysch, cannot have been due to lithospheric flexure in response to loading by thrust sheets. If the new model is correct, other mechanisms must be responsible for the creation of this space. Flexural modeling of the lithosphere beneath the Apennines by Royden and Karner (1984) has already shown that the thrust sheet load is too small. These authors suggested that the Pliocene foredeep must be the result of significant subsurface load in addition to loading by thrust sheets. Alternatively, the initial accommodation space could be due to extensional faulting ahead of the active thrust front. Recent work by Scisciani et al. (2001) concluded that both foreland and hinterlanddipping normal faults controlled the architectures of paleoforedeep basins, including the Laga and Cellino basins in the Central Apennines. In addition, Butler et al. (1992) suggest that the late Miocene foredeep in Sicily was limited by extensional faults; these are responsible for abrupt lithological and thickness variations of late Miocene sediments.
Shortening dominated by thick-skinned thrusting and folding in this area is consistent with the analysis of the external part of the Northern Apennines by Coward et al. (1999) and Butler et al. (in press). However, Butler et al. (in press) also report that major thin-skinned thrusting (45 km shortening) has occurred in the Molise region, just SE of the area analysed in this paper, with relatively limited thick-skinned deformation $(5 \mathrm{~km}$ shortening). The juxtaposition of the very different but adjacent structural styles in Lazio-Abruzzi (this study) and Molise (Butler et al., in press) suggests that a major transverse structure separates these areas. This is also identified in other regional studies (Ghisetti and Vezzani, 1991) and more detailed fieldwork (Mattei and Miccadei, 1991).

Petroleum geologists exploring for hydrocarbons within the mountain chain should be aware that the deep structure is poorly understood. Plays related to thrust faulting should be considered carefully, for whilst some wells (e.g. Trevi 1 and Antrodoco 1) have encountered older on younger relationships attributed to thrusting, other very deep wells (e.g. Villadegna 1, total depth $6907 \mathrm{~m}$ ) have not.

Ultimately, the two models presented here are likely to be the end members of a whole series of possible explanations for the surface geology and well data in the Central Apennines; the real section may contain elements of both models. Acquisition of addition deep seismic and well data in the future may resolve the issue. In particular, publication of the CROP11 (see Fig. 2 for location) deep seismic line may help resolve the fundamental issue of the degree of basement involvement, as did CROP03 in the Northern Apennines (Pialli et al., 1998).

\section{Conclusions}

A thick-skinned thrust tectonic model can successfully be applied to a section across the Lazio-Abruzzi carbonate platform in the Central Apennine thrust belt. Section restoration shows that this model requires considerably less shortening, $37 \mathrm{~km}$ over a section $158 \mathrm{~km}$ long, than predicted by previous thin-skinned models in which the sedimentary cover is detached from the basement $(172 \mathrm{~km}$ over $173 \mathrm{~km})$. In the new interpretation, shortening was characterised by a coupled deformation of both the basement and sedimentary cover as a result of reactivation of earlier extensional faults. Additional shortening was achieved by open buckling of the carbonate platform with a wavelength of $10 \mathrm{~s}$ of $\mathrm{km}$, and tighter folding of the thinner and more incompetent basin-scarp stratigraphy with folds nucleating in areas where early extensional faults were present.

Since both models fit the outcrop and well data, and can be restored, an additional test is required to suggest which is more likely to be correct. In this case age bracketing on the activity of thrust faults constrains the timing of deformation across the area, so that shortening rates can be calculated. These are $<6 \mathrm{~mm} \mathrm{yr}^{-1}$ for the new interpretation, but $>24 \mathrm{~mm} \mathrm{yr}^{-1}$ for the thin-skinned interpretation. This latter 
value is comparable with rates reported for the Himalayas, Andes, and Taiwan, but thrust belt shortening rates in the Mediterranean area are generally much lower. This suggests that thick-skinned tectonics provides a better explanation for the structure of this area.

The implications of this are that Neogene crustal shortening in this part of the Apennines is much less than recognised before; this should be considered by future paleogeographic and geodynamic models of the area. In addition, hydrocarbon exploration strategies based on repetition of suitable reservoir rocks beneath thrust faults may be very risky in the Central Apennines. Finally, calculation of shortening rates provides a simple additional test for balanced sections and should be carried-out wherever possible.

Acknowledgements. We are grateful to Professor Livio Vezzani for providing maps of the area, to BG Group for providing well logs, and to Pasquale Robustini and Stefano Gambini for useful comments on an earlier draft of this paper. R. Zoetemeijer and M. P. Coward are thanked for helpful reviews. Financial support from the NERC (award reference GT 04/99/ES/118) and BG Group is gratefully acknowledged.

\section{References}

Agip: Carta Magnetica D'Italia, 1981.

Alberti, A., Bergomi, C., Centamore, E., Cestari, G., Chiocchini, U., Salvati, L., and Manganelli, V.: Carta Geologica D’Italia, Foglio 389, Anagni, Scale 1:50 000, 1975.

Alberti, A., Bergomi, C., and Damiani, A.: Carta Geologica D'Italia, Foglio 376, Subiaco, Scale 1:50 000, 1997.

Argnani, A. and Gamberi, F.: Stili strutturali al fronte della Catena Appenninica nell'Adriatico centro-settentrionale, Studi Geologici Camerti, vol. speciale 1995/1, 19-28, 1995.

Banks, C. J. and Warburton, J.: "Passive-roof" duplex geometry in the frontal structures of the Kirthar and Sulaiman mountain belts, Pakistan, Journal of Structural Geology, 8, 229-237, 1986.

Barchi, M. and Bigozzi, A.: Ipotesi sulla geometria e la genesi dei bacini euxinici del Trias superiore in Appennino centrale, Studi Gologici Camerti, 1995/2, 53-62, 1995.

Barchi, M. R., Minelli, G., and Pialli, G.: The CROP03 profile: a synthesis of results on deep structures of the Northern Apennines, Mem. Soc. Geol. It., 52, 383-400, 1998a.

Barchi, M. R., De Feyter, A. J., Magnani, M. B., Minelli, G., Pialli, G., and Sotera, B. M.: Geological interpretation of the CROP 03 NVR seismic profile (stack), Mem. Soc. Geol. It., 52, 1998b.

Bally, A. W., Burbi, L., Cooper, C., and Ghelardoni, R.: Balanced sections and seismic reflection profiles across the Central Apennines, Mem. Soc. Geol. It., 35, 257-310, 1986.

Bigi, G., Cosentino, D., Parotto, M., Sartori, M., and Scandone, P.: Structural model of Italy and gravity map, CNR - Progetto Finalizzato Geodinamica, Quaderni de "La Ricerca Scientifica" n. 114, 3, 1990 .

Bilham, R., Larson, K., Freymueller, J., and Project Idylhim members: GPS measurements of present-day convergence across the Nepal Himalayas, Nature, 386, 61-64, 1997.

Bortolotti, V., Passerini, P., Sagri, M., and Sestini, G.: The Miogeosynclinal Sequences, Sedimentary Geology, 4, 341-444, 1970.
Buchanan, J. G. and Buchanan, P. G. (Eds.): Basin Inversion, 596 pp., Geological Society Special Publication, 88, 1995.

Butler, R. W. H., Grasso, M., and La Manna, F.: Origin and deformation of the Neogene-Recent Maghrebian foredeep at the Gela Nappe, SE Sicily, J. Geol. Soc., London, 149, 547-556, 1992.

Butler, R.W.H., Mazzoli, S., Corrado, S., De Donatis, M., Di Bucci, D., Gambini, R., Naso, G., Nicolai, C., Scrocca, D., Shiner, P., and Zucconi, V.: Applying thick-skinned tectonic models to the Apennine thrust belt of Italy: Limitations and implications, in: McClay, K. R. (Ed.): Thrust Tectonics and Petroleum Systems, AAPG Memoir, (in press).

Casero, P., Roure, F., and Vially, R.: Tectonic framework and petroleum potential of the southern Apennines, in: Spencer, A. M. (Ed.): Generation, accumulation and production of Europe's hydrocarbons, Special Publication of the European Association of Petroleum Geoscientists No. 1, pp. 381-387, Oxford University Press, 1991.

Cavinato, G. P., Cosentino, D., Funicello, R., Parotto, M., Salvini, F., and Tozzi, M.: Constraints and new problems for Geodynamical Modelling of Central Italy (Crop 11 Civitavecchia - Vasto deep seismic line), Boll. Geof. Teor. Appl., 36, 159-174, 1994.

Chiappini, M., Meloni, A., Boschi, E., Faggioni, O., Beverini, N., Carmisciano, C., and Marson, I.: Magnetic Anomaly Map at Sea level of Italy and surrounding areas - Total Intensity, Scale 1:1500000, Istituto Nazionale di Geofisica e Vulcanologia, 2001.

Cipollari, P. and Cosentino, D.: Miocene unconformities in the Central Apennines: geodynamic significance and sedimentary basin evolution, Tectonophysics, 252, 375-389, 1995.

Cipollari, P. and Cosentino, D.: Miocene tectono-sedimentary events and geodynamic evolution of the central Apennines (Italy), Notes et Mem. Serv. Geol. Maroc, 387, 163-176, 1996.

Cooper, M. A. and Williams, G. D. (Eds.): Inversion Tectonics, 375 pp., Geological Society Special Publication, 44, 1989.

Corrado, S., Di Bucci, D., Naso, G., and Butler, R. W. H.: Thrusting and strike-slip tectonics in the Alto Molise region (Italy): implications for the Neogene-Quaternary evolution of the Central Apennine orogenic system, J. Geol. Soc., London, 154, 679-688, 1997

Coward, M. P.: Thrust tectonics, thin skinned or thick skinned, and the continuation of thrusts to deep in the crust, Journal of Strutural Geology, 5, 113-123, 1983.

Coward, M. P.: Balancing sections through inverted basins, in: Buchanan, P. G. and Niewland, D. A. (Eds.): Modern Developments in Structural Interpretation, Validation and Modelling, Geological Society Special Publication, 99, 51-77, 1996.

Coward, M. P., De Donatis, M., Mazzoli, S., Paltrinieri, W., and Wezel, F.-C.: Frontal part of the northern Apennines fold and thrust belt in the Romagna-Marche area (Italy): Shallow and deep structural styles, Tectonics, 18, 559-574, 1999.

D’Agostino, N., Chamot-Rooke, N., Funiciello, R., Jolivet, L., and Speranza, F.: The role of pre-existing thrust faults and topography on the styles of extension in the Gran Sasso range (central Italy), Tectonophysics, 292, 229-254, 1998.

Devoto, G.: Sguardo Geologico dei Monti Simbruini (Lazio NordOrientale), Geologica Romana, 9, 127-136, 1970.

Doglioni, C.: Geological evidence for a global tectonic polarity, J. Geol. Soc., London, 150, 991-1002, 1993a.

Doglioni, C.: Some remarks on the origin of foredeeps, Tectonophysics, 228, 1-20, 1993b.

Dondi, L., Papetti, I., and Tedeschi, D.: Stratigrafia del pozzo Trevi 1 (Lazio), Geol. Rom. V, 249-262, 1966. 
Elliott, D.: The construction of balanced cross-sections, Journal of Structural Geology, 5, 101, 1983.

Faccenna, C., Davy, P., Brun, J.-P., Funicello, R., Giardini, D., Mattei, M., and Nalpas, T.: The dynamics of back-arc extension: an experimental approach to the opening of the Tyrrhenian Sea, Geophys. J. Int., 126, 781-795, 1996.

Ghisetti, F., Barchi, M., Bally, A. W., Moretti, I., and Vezzani, L.: Conflicting balanced structural sections across the Central Apennines (Italy): problems and implications, in: Spencer, A. M. (Ed.): Generation, Accumulation and Production of Europe's Hydrocarbons III, Special Publication of the European Association of Petroleum Geoscientists No. 3, pp. 219-231, SpringerVerlag Berlin Heidelberg, 1993.

Ghisetti, F. and Vezzani, L.: Carta Geologica del Gruppo M. Siella - M. Camicia - M. Prena - M. Brancastello (Gran Sasso d'Italia, Abruzzo), Scale 1:15000, 1986.

Ghisetti, F. and Vezzani, L.: Thrust belt development in the Central Apennines (Italy): northward polarity of thrusting and out-ofsequence deformations in the Gran Sasso chain, Tectonics, 10, 904-919, 1991.

Ghisetti, F. and Vezzani, L.: Interfering paths of deformation and development of arcs in the fold-and-thrust belt of the central Apennines (Italy), Tectonics, 16, 523-536, 1997.

Giardini, D. and Velonà, M.: Deep seismicity of the Tyrrhenian Sea, Terra Nova, 3, 57-64, 1991.

Hill, K. C. and Hayward, A. B.: Structural constraints on the tertiary plate tectonic evolution of Italy, Marine and Petroleum Geology, 5, 2-16, 1988.

Kendrick, E. C., Bevis, M., Smalley, R. F., Cifuentes, O., and Galban, F.: Current rates of convergence across the Central Andes: Estimates from continuous GPS observations, Geophysical Research Letters, 26, 541-544, 1999.

Larson, K. M., Burgmann, R., Bilham, R., and Freymueller, J.: Kinematics of the India-Eurasia collision zone from GPS measurements, J. Geophys. Res., 104, 1077-1093, 1999.

Lavecchia, G.: The Tyrrhenian-Apennines system: structural setting and seismotectogenesis, Tectonophysics, 147, 1988.

Lavecchia, G., Brozzetti, F., Barchi, M., Menichetti, M., and Keller, J.: Seismotectonic zoning in east-central Italy deduced from an analysis of the Neogene to present deformations and related stress fields, Geol. Soc. Am. Bull., 106, 1107-1120, 1994.

Lucente, F. P., Chiarabba, C., Cimini, G. B., and Giardini, D.: Tomographic constraints on the geodynamic evolution of the Italian region, J. Geophys. Res., 104, $20307-20327,1999$.

Mazzoli, S., Corrado, S., De Donatis, M., Scrocca, D., Butler, R. W. H., Di Bucci, D., Naso, G., Nicolai, C., and Zucconi, V.: Time and space variability of "thin-skinned" and "thick-skinned" thrust tectonics in the Apennines (Italy), Rend. Fis. Acc. Lincei, 9, 5-39, 2000.

Malinverno, A. and Ryan, W. B. F.: Extension in the Tyrrhenian Sea and shortening in the Apennines as result of arc migration driven by sinking of the lithosphere, Tectonics, 5, 227-245, 1986.

Mattei, M., Funicello, R., and Kissel, C.: Paleomagentic and struc- tural evidence for Neogene block rotations in the Central Apennines, Italy, J. Geophys. Res., 100, 17 863-17 883, 1995.

Mattei, M. and Miccadei, E.: Strike-slip tectonics between the Marsica Range and the Molisian Basin in the Sangro Valley (Abruzzo, Central Italy), Boll. Soc. Geol. It., 110, 737-745, 1991.

Meigs, A. J., Verges, J., and Burbank, D. W.: Ten-million-year history of a thrust sheet, GSA Bull., 108, 1608-1625, 1996.

Mostardini, F. and Merlini, S.: Appeninio Centro Meridionale: Sezioni Geologiche e Proposta di Modello Strutturale, Mem. Soc. Geol. It., 35, 177-202, 1986

Muñoz, J. A.: Evolution of a continental collision belt: ECORSPyrenees crustal balanced cross-section, in: McClay, K. R. (Ed.): Thrust Tectonics, pp. 235-246, Chapman and Hall, 1991.

Patacca, E., Sartori, R., and Scandone, P.: Tyrrhenian Basin and Apenninic Arcs: kinematic relations since late Tortonian times, Mem. Soc. Geol. It., 45, 425-451, 1990.

Parotto, M. and Praturlon, A.: Geological summary of the Central Apennines, Quaderni de "La ricerca scientifica", 90, 258-311, 1975.

Pialli, G., Barchi, M. R., and Minelli, G. (Eds.): Results of the CROP03 deep seismic reflection profile, Mem. Soc. Geol. It., 52, 657 pp., 1998.

Pieri, M. and Mattavelli, L.: Geologic framework of Italian Petroleum Resources, AAPG Bull., 70, 103-130, 1986.

Powers, P. M., Lillie, R. J., and Yeats, R. S.: Structure and shortening of the Kangra and Dehra Dun reentrants, Sub-Himalaya, India, Geol. Soc. Am. Bull., 110, 1998.

Royden L. and Karner, G. D.: Flexure of lithosphere beneath Apennine and Carpathian foredeep basins: evidence for an insufficient topographic load, AAPG Bull., 68, 704-712, 1984.

Scisciani, V., Calamita, F., Tavarnelli, E., Rusciadelli, G., Ori, G. G., and Paltrinieri, W.: Foreland-dipping normal faults in the inner edges of syn-orogenic basins: a case from the Central Apennines, Italy, Tectonophysics, 330, 211-224, 2001.

Sinclair, H. D.: Tectonostratigraphic model for underfilled peripheral foreland basins: An Alpine perspective, Geol. Soc. Am. Bull., 109, 324-346, 1997.

Segre, A. G., Cocozza, T., Angelucci, A., and Sirna, G.: Carta Geologica D'Italia, Foglio 159, Frosinone, Scale 1:100 000, 1966.

Segre, A. G. and Motta, S.: Carta Geologica D'Italia, Foglio 158, Latina, Scale 1:100 000, 1963.

Yu, S.-B., Chen, H.-Y., and Kuo, L.-C.: Velocity field of GPS stations in the Taiwan area, Tectonophysics, 274, 41-59, 1997.

Tavarnelli, E.: The effects of pre-exisiting normal faults on thrust ramp development: an example from the Northern Apennines, Italy, Geol. Rundsch., 85, 363-371, 1996.

Vann, I. R., Graham, R. H., and Hayward, A. B.: The structure of mountain fronts, Journal of Structural Geology, 8, 215-227, 1986.

Vezzani, L. and Ghisetti, F.: Carta Geologica Dell'Abruzzo, Scale 1:100 000, 1998 